\title{
Impact of corporate social responsibility on organization's financial performance: evidence from Maldives public limited companies
}

\author{
Ibrahim Sameer ${ }^{*}$ (1)
}

\begin{abstract}
The main objective of this study is to determine the CSR disclosure and to find out the association between CSR and FP by the public companies of Maldives. This study used a mixed-method research choice and is longitudinal research. The study period was from 2014 to 2018. Data were collected from annual reports of the listed companies in MSE. The sampling technique used was judgmental sampling, and the data were analyzed from STATA 15 software by using panel data regression. The finding reveals that diversity and ROA, environment and ROE, diversity, and EPS, and when the size of the firm controlled, there exhibit significant negative relation between CSR and ROA; hence, it can conclude that there exists a significant negative relationship between CSR and FP. This study has implications for the academician and corporate world in understanding CSR and FP in developing countries like the Maldives. One of the main consequences of this study is the CSR framework adopted in this study which is not a custom-tailored instrument specific to the Maldives instead chose from another research paper. Further, the sample size was also very limited due to that generalization may not be possible in a large population. This paper spreads the understanding of the relationship between CSR and FP.
\end{abstract}

Keywords: Corporate social responsibility, Financial performance, Maldives, Return on assets, Return on equity and earning per share

\section{Introduction}

Corporate social responsibility (CSR) is one of the most controversial and significant topics since the 1950s, and it has been growing since then [29]. CSR discipline is one of the rigorous research areas among practitioners and academicians [28]. In the history of the corporate world for the first time, CSR was mention by Bowen [21] in his seminal book Social Responsibility of the Businessmen in 1953. In his book, the central question, he argues that and continues to be asked, was "what is the responsibilities to society may businessmen reasonably be expected to assume." Bowen [21] also stresses the importance of

\footnotetext{
*Correspondence: Ibrahim.sameer@ium.edu.mv
}

Islamic University of Maldives, Malé, Maldives knowing business ethics so that it can lead to superior enduring performance. Cruz et al. [43] confirm that CSR initiatives are significant in the context of business ethics and found a healthy positive attitude toward business ethics and CSR.

Despite the long history of CSR discipline, up to date, it remains to be debatable and immature in some areas. For instance, one area that is debatable and one of the central focus given is determining the relationship between CSR and corporate financial performance (CFP). According to Das and Bhunia [47], the whole literature on this area can be categorized into three. Some studies show a positive correlation between CSR initiatives on FP $[167,197]$ and Yeganeh and Barzegar [7]. On the other hand, Hirigoyen and Rehm [78] and Madugba and Okpara [118] found 
negative correlation between CSR and FP. Lastly, [35, 104] found no correlation between CSR and FP.

During the past six decades of CSR discipline, numerous finding has caught the attention of CSR practitioners and academicians [195]. These studies results suggest that CSR provides insurance like effect on financial performance against adverse events of company [147, 203, 204], CSR initiatives can enhance employee organizational commitment and organizational performance [5], and most of the workers like to work and can attract more potential employees for an organization that has an excellent reputation for being socially responsible $[69,77$, $112]$. Therefore, now a day to pursue sustainable development and enhance the goodwill of companies has started to publish CSR disclosures in annual company report or CSR reports.

In the Maldives, it is not mandatory for public companies to publish the CSR report. Nowadays, companies announced CSR disclosure through the annual report. It indicates the prominence given by companies to CSR activities, but the effect of CSR on financial performance is not locally being investigated so far in the Maldives, due to several reasons. First, research base culture did not exist in the Maldives and recently public university came into the picture. Secondly, public companies in the Maldives assume that similar management practices (such as CSR) adopted by foreign countries might be relevant in the Maldives. According to [181], most of the research done on CSR is investigated in a western developed nation such as the USA, UK, Germany, and Australia and is not that clear whether it can apply in developing nations. Burton et al. [25] and Khan [97] suggested that to understand CSR, it is a must to understand the cultural aspects of that country because developed nations' influential factors may not apply to the Maldives. Third, there is no CSR measurement practice in the Maldives and how it should report. Fourth, the impact of CSR on financial performance has not been investigated locally so far in the Maldives. Due to these reasons, it is worth investigating the association between CSR and financial performance.

From the above discussion, it is clear that most of the research done on CSR was dominated by a western developed nation such as the USA, UK, Germany, and Australia [181]. According to Das and Bhunia [47] though there are intensive empirical research done in order to find relationship between CSR on FP [14, 62, 137], the result of previous studies is indeterminate. Hence, this is a gray area with inconclusiveness, and this research gap motivates the researcher to conduct a study on this topic.

According to Wang et al. [196], there are numerous researches on CSR discipline in respect of FP in foreign countries, especially in developed nations, indicating a dearth of studies in the Maldives context. As per the researcher's knowledge so far, there is only one study done [175] in the local context on CSR. In that research, the author investigates the CSR context in the Maldives and has not explored the CSR and FP relation. Hence, this provides a gap for further studies in finding the relationship between CSR and FP in public listed companies in the Maldives. Therefore, this study of CSR and FP in public listed companies in the Maldives tries to attempt to fill this gap in the literature.

- To establish whether CSR (community, workplace, environment and diversity) positively/negatively correlated with Financial Performance (FP) of public companies in Maldives using ROA.

- To determine whether CSR (community, workplace, environment and diversity) positively/negatively correlated with Financial Performance (FP) of public companies in Maldives using ROE.

- To decide whether CSR (community, workplace, environment and diversity) positively/negatively correlated with Financial Performance (FP) of public companies in Maldives using EPS.

Following this brief introductory section, the rest of the paper is divided in the following manner: "Literature review" section discusses the meaning of CSR, why companies engage in CSR and empirical evidence of CSR and FP and theoretical framework. "Research methodology" section discusses the data collection and sampling procedure, model used in the study and the specification test. "Finding and analysis" section presents the empirical findings and discussion of the results, and finally, "Conclusion" section is the conclusion of the paper.

\section{Literature review}

According to [27], there were a vast number of definitions of CSR that have emerged in the academic literature. Some of the notable contributors that have defined CSR include [21, 30, 56, 91]. In general, CSR can be defined as its responsibility toward its ecosystem.

Although there is a diverse definition given by scholars around the globe about CSR, there is no universally accepted definition of CSR [45]. Dahlsrud analyzed 37 most commonly used definitions of CSR. He concluded that there is a lot of congruency in the description and suggested that there are five dimensions in all the explanations and those are environmental, social, economic, stakeholders, and charity dimension. In the same tone [161] stated that there is no unique definition of CSR that can be acceptable around the globe. Finally, Hamidu et al. [72] reviewed CSR definition, its core characteristics, and theoretical perspective. They have suggested that in 
the academic world, there is no clear agreed definition of CSR, and the lack of homogeneity in the definition of CSR is due to the ever-shifting roles of CSR in the corporate world.

\section{Empirical evidence regarding the relationship between CSR and FP}

In the academic literature, the theoretical linkage between CSR and FP of the organization found inconsistency results $[122,139]$. Hence, the body of knowledge in this regards can be categorized into three spectra that is some argue that CSR can enhance FP of the organization, other researchers argue that CSR rather reduced firms' performance, and finally, other schools of thought argue that there exists no relation between CSR and organization performance. Table 1 describes the summary of empirical findings of CSR and FP researches, and also it highlights the different variables used in the various study.

Researchers that are in favor of CSR and FP linkage argue that when company initiates CSR activities, it creates positive image in the mind of stakeholders; hence, the more company satisfy its stakeholders, the better financial performance of the company [51, 53]. Likewise, the other proponents on this linkage advocate that by satisfying the interest of stakeholders and being more accountable to them can have positive effects on the financial performance of the company [38, 151, 201]. In light of stakeholder's theory, $[19,135]$ stated that consumers are willing to pay premium price for CSR initiatives companies' products, and CSR activities can improve the image of the company among consumers and it help to improve customer loyalty [123, 150, 158, 173]. Likewise, Turban and Greening [184] posit that CSR firms can attract more potential applicants, which in turn can be a competitive advantage for the organization. Another recent research done by them [68] documented that socially responsible companies can attract more talented employees to work on that organization, and also CSR firms can retain their employees over a long period, hence, it can lead to a competitive advantage over other companies. The proponent believed that engaging CSR-related programmed can benefit the organization in several ways, such as reduction in labor turnover [206], enhance reputation of company and achievement of business strategy [86, 207], created sense of belongingness [34], attract more talented staffs [92, 117], job satisfaction [109] and Sharma and Mishra [162] and be more committed to their work $[20,54]$.

Conversely to the above argument, [58] advocates that there is only one responsibility of a corporate firm that maximizes shareholders' wealth. In line with this argument, [143] supports [58] claim stating that CSR is motivated by a socialist-collectivist agenda which are in paradox with capitalist/libertarian values of free enterprise and individualism. Furthermore, [132] suggest that the consumer does not check whether it is an SR company or not when making purchase decisions. But [140] documented that when making purchase decision consumer do take whether it is an SR company or not but the positive attitudes of consumer not transferred into actual purchase decision of consumer and this further being supported by [64] stating that buying SR product is a "moral duty" and this duty can be overridden by other preferences of consumer especially if it is budget consumer. Hence, this line of argument was stress by [58] documented that organization manager use firms' resources for non-profit social activities at the expense of shareholders, and this has been supported by [88] in the "agency cost problem" which stated that the CSR cost incurred outweigh the benefits it brings to the company.

In the academic literature, the early research that supports the inverse relationship between CSR and FP is [105, 157, 188]. Vance's [188] support [58] preposition founds that being socially responsible does not bring any economic benefits to the company, rather, it reduces company stock returns. Further, this has validated by [11] who documented that the firm level of SR hinders FP compared to rivals. Likewise, [157] stated that engaging CSR activities lead wasting firms' resources that can use in more productive opportunity for the firms. Further, they argue that managers of the company may engage in CSR not to increase shareowners' wealth, instead gain personal benefits. Looking into more recent studies on this line of the argument states that CSR is a manifestation of agency problem and is done at the expense of shareowner [80]. Moreover, [102] supported the findings of [157] and stated that the organization manager gets a good reputation at the expense of shareowner by investing more in CSR and also suggest that when the organization releases positive CSR news, then investors react slightly negative to those disclosures. Bhandari and Javakhadze [18] reveal that when an organization wants to satisfy its broad stakeholder's entire group, then it may need to forgo lots of positive NPV project that may increase the shareholder's wealth.

The academic debate on CSR and FP has another possibility that both these are mutually exclusive, meaning CSR has no significant impact on FP of a company [122, 139]. The scholars of this line of reasoning argue that CSR has no effect on financial performance of companies [61, $95,137]$. There are several studies conducted across the globe in finding the linkage between CSR and FP of specific industries or countries [55] and industries or countries specific research is incomplete up to date [44]. Kiliç [99] investigated online CSR disclosure practices by 25 


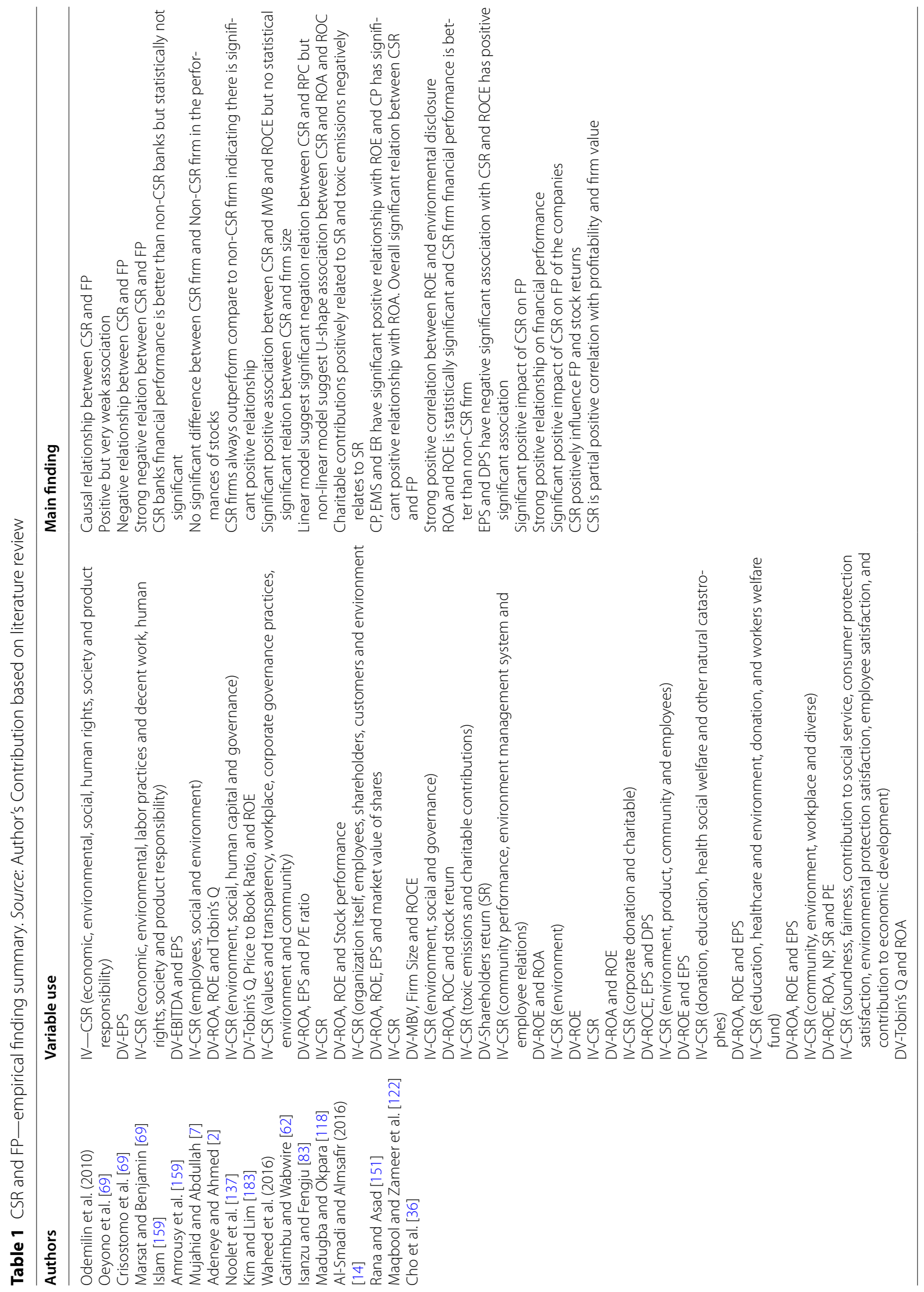


banks in Turkey, the results suggest that all the banks in the country do at least disclose one dimension of CSR on the corporate website and also documented that highly visible banks disclose more information compared to the less visible bank. Furthermore, Pérez and Del Bosque [148] and Pratihari and Uzma [156] investigated CSR disclosure in Spain (former), and India (latter) founds that CSR positively impacts a customer in identifying the bank and CSR helps company in building brand and customer loyalty. Due to stated reasons, $[14,83]$ found a positive association between CSR and FP. On the other hand, the influence on industry characteristics is also another area that has been investigated by scholars. For example, [15] called for more research to be done on potential heterogeneity of CSR's influence on organizational performance across different industries. The reason for that is due to the impact the organization that brings to society is different. For instance, compared to other industries (such as banking, tourism and retail), the controversial sector (e.g., tobacco, alcohol, petroleum, utility, and steel) harms the environment more [89]. Therefore, [177] suggested that controversial industries are exposed more to the environment and social risk; therefore, companies in these industries need to do more CSR activities to gain the confidence of stakeholders.

Looking into empirical side of CSR and FP indicated positive relation mostly in developed and developing nation [14, 42] and Maqbool and Bakr [162]. Conversely, some empirical studies show the inverse relationship between CSR and FP [169] and Hirigoyen and Rehm [78]. Yet there is body of empirical knowledge that do not support either of the above argument and those scholars found neutral or no relation between CSR and FP [95, $109,137,163]$.

Though there are controversies in the above empirical studies, [32, 142] conducted two different meta-analysis using 30 years of data. The authors have documented that CSR positively correlated with CFP. Further, another meta-analysis conducted by [17] also found that there is clear empirical evidence for a positive relation between CSR and FP. Conversely [123] meta-analysis of 251 studies documented positive (but small) association between CSR and FP. But meta-analysis of [146] included 159 reviews and recorded that $63 \%$ of the studies show positive, $15 \%$ indicated the contrary, and $22 \%$ shows a neutral or mixed association between CSR and FP.

In light of above discussion, it is clear that CSR and FP are inclusive in the academia. Therefore, this paper tries to investigate empirically whether there is any association between CSR and FP in developing nation such as Maldives. Most of the literature done in this discipline is in the developed nations, few studies in the developing nation, and no studies in the context of Maldives.
Furthermore, this study tries to fill the imbalance that is there in the academia when public advocate companies in Maldives become more CSR orient. Hence, different hypotheses developed for this paper are given under conceptual framework (Fig. 1).

\section{Research methodology \\ Population and sample}

This study focuses on listed companies of MSE. At present, there are eight companies listed in the stock exchange; two companies do not fit in the study period because the study period of this research is from 2014 to 2018. For this study, the remaining six companies' data have taken as a sample (75\% of the population). This study adopts non-probability sampling and uses judgmental sampling techniques. Judgmental sampling is more useful when the researcher desires to collect data from a specific group to bring more reliable and precise results [171, 179]. Žmuk et al. [208] recommended that if the researcher's target population is small, then to get satisfactory precision and accuracy level of the parameter of the estimate, researcher needs to include $70 \%$ of the samples population; here, in this study researcher study $75 \%$ of the population.

\section{CSR framework for this study}

It has been observed that CSR disclosure made by Maldivian Public companies is voluntary, and also it has been observed that there is no specific CSR framework in the Maldives. In determining CSR disclosure in academia, there are many different indices used in measuring CSR disclosure. The most well-known indices include: Dow Jones Sustainability Index [37], Fortune magazine reputation index [159], Global Reporting Initiative [113], MSCI KLD 400 social index [160] and Vigeo Index [100].

These indices have widely used in academia for measuring CSR performance (Waddock and Graves [191]). CSR disclosures vary between countries to countries, and there is no "one size fit all" approach [79]. For example, [199] argues national culture, political, and the civil system which often determines CSR disclosure. Xiao et al. [202] stated that CSR disclosure depends on the stage of social and economic development of the country. Moreover, [46] noted that the theories that are in the developed countries might not be entirely applicable due to different drivers of CSR. Conversely, in developing countries, CSR is more toward the economic environment (such as creating more jobs), filling government shortfall areas, and philanthropic charitable donations and ethics.

Furthermore, [59] stated that at this time, there is no generally accepted CSR reporting standard across the globe. In the same vein, [180] noted that the western world CSR concept could not be adapted as it is. It 


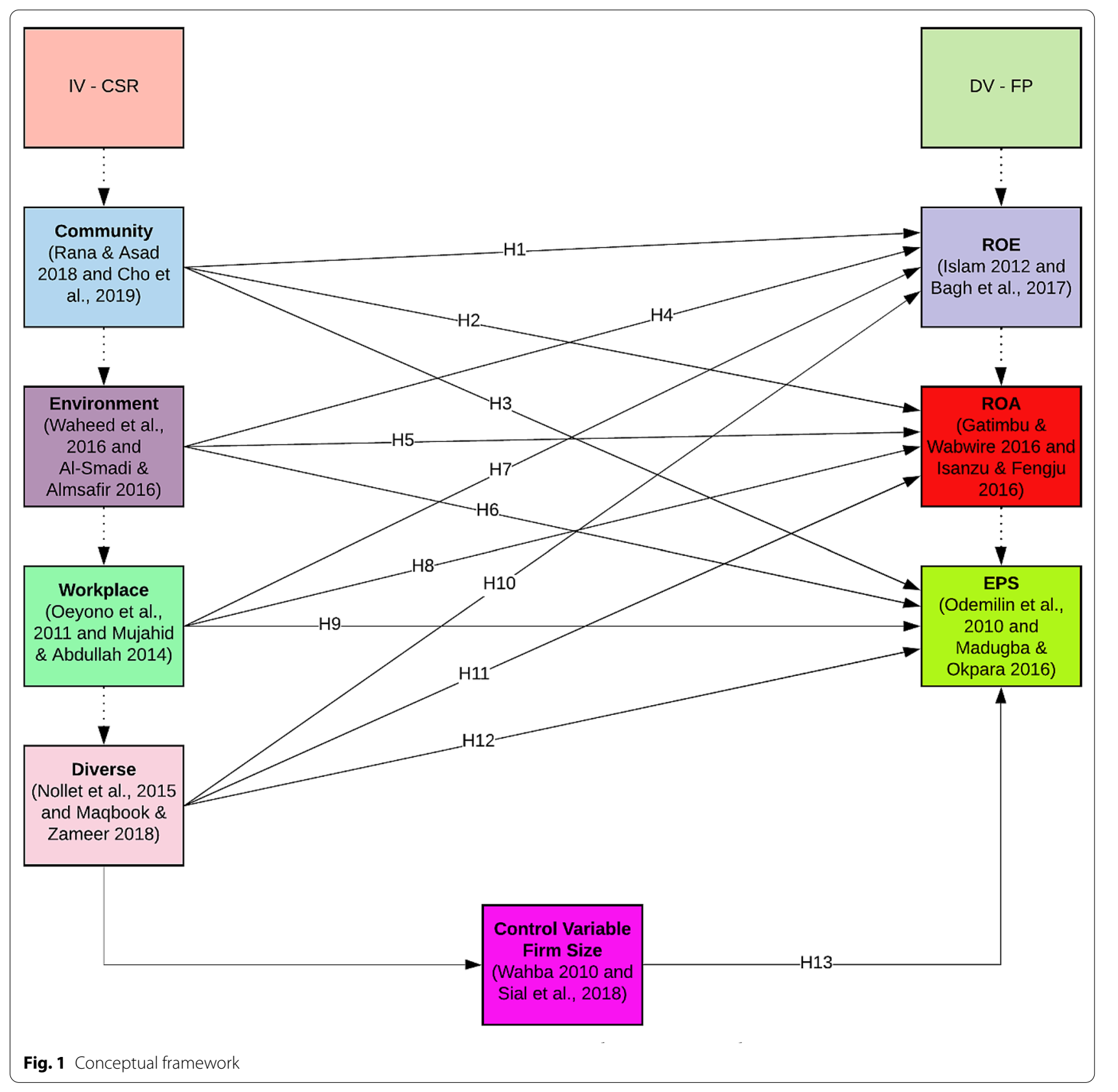

required modification based on the country/geographical needs. Therefore, in this study researcher is going to use the CSR standard developed by [122]. The adoption of this "CSR instrument" for this study is due to three reasons. Firstly, they have designed that instrument by taking into account different international standards, and academic literature [165], Centre for Corporate Research and Training 2003, Confederation of Indian Industry 2002). Secondly, it is developed based on the developing nation's cultural needs and thirdly very latest instrument.

\section{Content analysis and coding procedure}

This study uses the content analysis technique and uses the annual report to developed CSR index for public companies in the Maldives. Content analysis is a technique that has been commonly used in social science research for quite a long period [3]. Further, this method has been quite often used in CSR and FP research as well $[62,95]$.

In content analysis, themes must be developed to make an inference from the data. In line with this reasoning, 
Milne and Adler [130] stated that construction and categorization of schemes are the essential part when using content analysis. This research adopted the [122] CSR framework; hence, the researcher used the categories of [122] CSR framework. It includes mainly four components, namely community, environment, workplace, and diversity. In this study, each public company listed in MSE has coded about different CSR disclosure categories identified in the annual report. Companies CSR is measured using adopted CSR framework under each category, there are eight different themes, and based on that researcher decides whether it is CSR disclosure or not.

One of the prerequisites of content analysis is that it requires systematic coding using predetermine criteria [70]. For this study, the different keyword used is the work of [122] CSR framework. This makes the coding process straightforward, and also it lessens the prejudice in determining CSR disclosure and how to categorize them. When the keyword and categories are used, it helps in decision rules, and also it improves the reliability and accuracy of the coding process [130]. For this study, the researcher uses the unit of analysis as a "sentence."

The procedure used in the content analysis of this study is that two independent coders were selected. Before coding and classification process begins, these two coders are given full training by the researcher on CSR disclosure, use of coding instruments, and explanation of different categories and types of disclosure in [122] CSR framework. In order to check degree of reliability and accuracy of intercoder, this study used four main methods that are used in checking the validity of content analysis [62, 95], that is percentage of agreement $[41,178]$, Scott's $\pi$ [174], Cohen's $\kappa$ [41] and Krippendorff's $\alpha$ [101]. The intercoder reliability test of this study is presented in the below table.

After reviewing different methodologies in the content analysis, [136] suggested that a reliability test coefficient value higher than 0.90 would be acceptable at all levels, and any amount above 0.80 would be acceptable in most cases and stated that there exists a significant disagreement between the coder. Therefore, based on the accuracy benchmark suggested by [136], the results are cited in Table 2, and all the reliability test values are higher than 0.90 . Hence, it is safe to conclude that the reliability of this study is considerably high because the reliability test values are significantly higher than benchmark values.

\section{Data collection procedures and sampling}

In this study, the content analysis is used in extracting CSR information from the annual reports of the company, and CSR has been divided into four categories (community, environment, workplace and diverse)
Table 2 Intercoder reliability test

\begin{tabular}{lllll}
\hline Details & $\begin{array}{l}\text { Percentage } \\
\text { agreement }\end{array}$ & Scott's Pi & $\begin{array}{l}\text { Cohen's } \\
\text { kappa }\end{array}$ & $\begin{array}{l}\text { Krippendorff's } \\
\text { alpha } \\
\text { (nominal) }\end{array}$ \\
\hline $\begin{array}{c}\text { Variable 1 } \\
\text { (cols 1 } \\
\text { and 2) }\end{array}$ & $96.9 \%$ & 0.963 & 0.963 & 0.964 \\
\hline
\end{tabular}

covering 32 items, to change qualitative information present in the annual report; this study used content analysis and changes that qualitative data to quantitative information using a dichotomous approach. In the dichotomous approach, if the item is disclosed (CSR instrument), then " 1 " is given, and if items not disclosed, then "0" and total CSR score of " $T$ " company is calculated based on the following formula.

$$
T=\sum_{t=1}^{n} \mathrm{di}
$$

where $\mathrm{di}=$ " 1 " if disclosed and " 0 " if not disclosed. $n=$ maximum number of disclosed.

In this study, the proxy of CSR categories is considered as community, environment, workplace, and diverse, and the FP proxy is considered as ROA, ROE, and EPS, and moderating variables considered as firm size. The following section details down how the ration is calculated.

Return on asset (ROA) ROA measures profits as a percentage of total assets, and ROA gives an impression to the investors how efficient the company in managing its assets in generating profits. The higher the ROA, better it is, and the formula used in calculating ROA is given below [69]:

$$
\mathrm{ROA}=\frac{\text { Net Income }}{\text { Total Assets }}
$$

Return on equity (ROE) ROE measures profits as a percentage of total shareholders' equity, and ROE gives an impression to the investors how efficient the company is generating profits using its shareholder's funds, or in other words, it measures profits made on each dollar of shareholders' funds. ROE is calculated using the below formula [69]:

$$
\text { ROE }=\frac{\text { Net Income }}{\text { Total Shareholders Equity }}
$$

Earning per share (EPS) EPS measures earning made for each common stockholders, and it also shows how much 
money the company is making for its stockholder; as a rule of thumb, if EPS is higher, better it is. EPS is calculated using the below formula [69]:

$$
\text { EPS }=\frac{\text { Net Income }}{\text { Common share Outstanding }}
$$

Firm size In the academic literature on CSR discipline, different scholars have used different control variables [193] such as firm size, firms age, firms leverage, capital intensity, and industry heterogeneity. For this study researcher going to use "firm size" as the control variables, the reason for that is because previous research has shown that larger firm tend to spend more on CSR than smaller firm [168], larger firm seen as the leader of the industry or they are the playmaker in the industry [76]. To measure the firm size, this study used the natural logarithm of total assets and is calculated using the following formula:

Total Assets (Natural Logarithm) $=\mathrm{LN}($ Total Assets $)$

\section{Panel data analysis}

To test the hypothesis, "Stata 15" software is used for quantitative data analysis. The data were gathered from 2014 and 2018 to test the relationship between CSR and FP. To test the relationship between CSR and FP, many scholars have used regression analysis [36, 38]; however, this kind of analysis was critics by its multicollinearity errors [189]; hence, to avoid that error this research is going to used panel data, and panel data have widely been used in academia in order to check the relationship between CSR and FP $[111,180]$.

\section{The model used in the study}

The CSR dimensions used in this research are community, environment, workplace and diverse; on the other hand, financial performance dimensions used are ROA, ROE, and EPS, and the control variable used in this study is the firm size. The independent variable and dependent variables of this study are CSR and FP, respectively. To estimate the direct relationship between CSR and FP, the three dependent variables (ROA, ROE, and EPS) equation used in this study can be expressed in the following ways:

$$
\begin{aligned}
\operatorname{ROA}_{i t}= & \alpha_{i t}+\beta_{1} \operatorname{Comm}_{1 i t}+\beta_{2} \operatorname{Div}_{2 i t} \\
& +\beta_{3} \operatorname{Env}_{3 i t}+\beta_{4} \text {Wor}_{4 i t}+\varepsilon_{i t} \\
& \mathrm{ROE}_{i t}=\alpha_{i t}+\beta_{1} \operatorname{Comm}_{1 i t}+\beta_{2} \operatorname{Div}_{2 i t} \\
& +\beta_{3} \operatorname{Env}_{3 i t}+\beta_{4} \text {Wor}_{4 i t}+\varepsilon_{i t} \\
& \mathrm{EPS}_{i t}=\alpha_{i t}+\beta_{1} \text { Comm }_{1 i t}+\beta_{2} \operatorname{Div}_{2 i t} \\
& +\beta_{3} \text { Env }_{3 i t}+\beta_{4} \text { Wor }_{4 i t}+\varepsilon_{i t}
\end{aligned}
$$

where $\mathrm{ROA}=$ return on assets, $\mathrm{ROE}=$ return on equity, $\mathrm{EPS}=$ earning per share, $\mathrm{Comm}=$ community, Div $=$ diverse, Env $=$ environment and Wor $=$ work.

To estimate the indirect relationship between CSR and FP, the moderating variables are included in the above equation, and it can be stated in the following ways:

$$
\begin{aligned}
\text {ROA }_{i t}= & \alpha_{i t}+\beta_{1} \text { Comm }_{1 i t}+\beta_{2} \text { Div }_{2 i t}+\beta_{3} \text { Env }_{3 i t} \\
& +\beta_{4} \text { Wor }_{4 i t}+\beta_{5} \text { Fsize }_{5 i t}+\varepsilon_{i t} \\
& \text { ROE }_{i t}=\alpha_{i t}+\beta_{1} \text { Comm }_{1 i t}+\beta_{2} \text { Div }_{2 i t}+\beta_{3} \text { Env }_{3 i t} \\
& +\beta_{4} \text { Wor }_{4 i t}+\beta_{5} \text { Fsize }_{5 i t}+\varepsilon_{i t} \\
& \text { EPS }_{i t}=\alpha_{i t}+\beta_{1} \text { Comm }_{1 i t}+\beta_{2} \text { Div }_{2 i t}+\beta_{3} \text { Env }_{3 i t} \\
& +\beta_{4} \text { Wor }_{4 i t}+\beta_{5} \text { Fsize }_{5 i t}+\varepsilon_{i t}
\end{aligned}
$$

where $\mathrm{ROA}=$ return on assets, $\mathrm{ROE}=$ return on equity, $\mathrm{EPS}=$ earning per share, $\mathrm{Comm}=$ community, Div = diverse, $\quad E n v=$ environment,$\quad$ Wor $=$ work and Fsize $=$ firm size (natural logarithm of total asset).

In this study, three different kinds of panel data models are used, namely the pool regression model by OLS (ordinary least square), fixed-effect model, and randomeffects model. In the pooled regression model, it pooled all the data together, ignoring the time series and crosssection nature of the data; hence, when pool regression combined all the data into one, it ignores the heterogeneity of the data that may exist [152].

The next model that is there is a fixed effect model (FEM) or LSDV model (least square dummy variables). This method allows for individual differences, meaning that it will enable heterogeneity compared with the OLS method. FEM methods are used in social science and business management research, by various academicians $[13,40]$. The main advantage of using this method is that it estimates the effects of independent variables on the dependent variable while controlling the effects of unobserved variables [162].

The last but not the least model used in this study is the random effect model (REM). One of the assumptions of REM is that the individual-specific effects are not correlated with the independent variables. Therefore, in the REM model, it can have varying interception value between cross-sectional data, and this variation is purely random. The main advantage of REM is it helps in controlling for unobserved heterogeneity when the heterogeneity is constant over time. The FEM and REM model can be denoted in the following formula, respectively:

$$
\begin{aligned}
& y_{i t}=\left(\alpha+u_{i}\right)+X_{i t}^{\prime} \beta+v_{i t} \\
& y_{i t}=\alpha+X_{i t}^{\prime} \beta+\left(u_{i}+v_{i t}\right)
\end{aligned}
$$

where $u_{i}$ is a fixed or random effect specific to individual (group) or time period that is not included in the 
regression, and errors are independent identically distributed, $v_{i t} \sim \operatorname{IID}\left(0, \sigma_{v}^{2}\right)$.

\section{Specification test for the study}

For this study, the researcher used three above discussed model, and to choose the best model, the following specification test has been carried out to select the best model.

Pooled OLS model or FEM model This test examined whether pooled OLS or FEM model is best in examining the group effect in the panel data set. The hypothesis significance can be check through $F$-test value; if the null hypothesis is accepted, then pooled OLS is better than the FEM model [200]. The null hypothesis is stated in the following manner:

$$
H_{0}=\mu_{1}+\mu_{n-1}
$$

Pooled OLS model or REM model This test examined whether pooled OLS or REM model is best in examining the random effect in the panel data set. REM can be tested through the Breusch-Pagan Lagrange multiplier (LM) test [200]. The hypothesis significance can be checked through Chi-square value; if the null hypothesis is accepted, then pooled OLS is better than the REM model. The null hypothesis can be stated in the following manner [4]:

$$
\sigma_{i t}=0
$$

FEM or REM model: Durbin-Wu-Hausman test (Hausman specification test) Hausman specification test runs to check whether FEM or REM is the most appropriate model in the panel data. The Hausman statistic $\chi^{2}$ is computed from the following formula [4].

$$
H=(\beta c-\beta e) \iota^{1}(V c-V e) t^{-1}(\beta c-\beta e)
$$

where $\beta c$ is the coefficient vector from the consistent estimator. $\beta e$ is the coefficient vector from the efficient estimator. Vc is the covariance matrix of the consistent estimator. $\mathrm{Ve}$ is the covariance matrix of the efficient estimator.

The hypothesis for Hausman specification test can be stated as follows:

$$
\begin{aligned}
& H_{0}=\text { REM is more appropriate model } \\
& H_{a}=\text { FEM is more appropriate model }
\end{aligned}
$$

If the $p$ value is less than $5 \%$, then reject the null hypothesis and accept an alternative hypothesis meaning that in that case, the FEM model is more appropriate than the REM model. On the other hand, if the $p$ value is

\begin{tabular}{|c|c|c|c|c|c|c|}
\hline \multirow[t]{2}{*}{ Variables } & \multicolumn{2}{|l|}{ Pooled OLS } & \multicolumn{2}{|c|}{ Fixed effects } & \multicolumn{2}{|c|}{ Random effects } \\
\hline & Coefficient & $P$ value & Coefficient & $P$ value & Coefficient & $P$ value \\
\hline Community & 0.0594373 & 0.625 & -0.0772663 & 0.428 & -0.0293367 & 0.711 \\
\hline Diverse & -0.4039215 & 0.013 & -0.4967378 & 0.044 & -0.3545431 & $0.044^{*}$ \\
\hline Environment & -0.5042016 & 0.005 & -0.0879446 & 0.584 & -0.1405709 & 0.321 \\
\hline Work & 0.4358209 & 0.007 & 0.1663909 & 0.284 & 0.2344171 & 0.065 \\
\hline Constant & 0.2204 & & 0.3501 & & 0.2162 & \\
\hline$R$-squared & 0.3540 & & 0.0026 & & 0.2568 & \\
\hline$P$ value $(F)$ & 0.0230 & & 0.1425 & & 0.0944 & \\
\hline \multicolumn{7}{|l|}{ F-test } \\
\hline Chi-square & & & 19.46 & & & \\
\hline$P$ value & & & 0.0000 & & & \\
\hline \multicolumn{7}{|c|}{ Lagrange multiplier test } \\
\hline Chi-square & 26.39 & & & & & \\
\hline$P$ value & 0.0000 & & & & & \\
\hline \multicolumn{7}{|l|}{ Hausman test } \\
\hline Chi-square & & & & & 1.12 & \\
\hline$P$ value & & & & & 0.8919 & \\
\hline
\end{tabular}
more than $5 \%$, then accept the null hypothesis meaning that the REM model is more appropriate than the FEM model $[4,200]$.

Table 3 Panel data analysis results with $\mathrm{ROA}$ as the dependent variable

The result is evaluated based on a $95 \%$ level of significance 


\section{Findings and analysis}

\section{Relationship between CSR and FP}

\section{Dependent variable: $R O A$}

In assessing the impact of CSR and FP, Table 3 shows the results obtained from the regression analysis between the independent variables, which are data capturing the CSR and the dependent variable represented by ROA. The panel analysis for the pooled, fixed, and random effect model is presented below without the control variable.

The specification test shows that the random model is the most appropriate model for this analysis. The $R$-squared of 0.2568 indicates that the independent variables explain about $25.68 \%$ of the variability in the dependent variable ROA. Furthermore, the result shows that there is a strong negative relationship between

Table 4 Random effect with control variable (firm size)

\begin{tabular}{|c|c|c|}
\hline \multirow{2}{*}{$\begin{array}{l}\text { Random effect model } \\
\text { Variables }\end{array}$} & \multicolumn{2}{|c|}{$\begin{array}{l}\text { Effect of the control variable } \\
\text { (size) }\end{array}$} \\
\hline & Coefficient & $P$ value \\
\hline Community & -0.0177123 & 0.833 \\
\hline Diverse & $-0.447828^{*}$ & 0.000 \\
\hline Environment & 0.2637665 & 0.144 \\
\hline Work & 0.2082073 & 0.058 \\
\hline Size & $-0.0322076^{*}$ & 0.000 \\
\hline Constant & 0.7289 & \\
\hline$R$-square & 0.7076 & \\
\hline F-test & 0.0000 & \\
\hline Chi-square & 58.08 & \\
\hline$P$ value & 0.0000 & \\
\hline
\end{tabular}

The result is evaluated based on a $95 \%$ level of significance diversity and ROA, while the result did not show a significant relationship between community, environment, work, and ROA. The random effect model can be specified below as follows:

$$
\begin{aligned}
\mathrm{ROA}= & 0.2162-0.0293_{\mathrm{comm}}-0.3545_{\mathrm{div}} \\
& -0.1406_{\mathrm{env}}+0.2344_{\mathrm{wor}}
\end{aligned}
$$

After controlling for the size of the company, the result shows that size has a highly statistical significant $P$ value of 0.000 . However, the relationship between size and the ROA of firms exhibits a negative relationship, as shown in Table 4. The result further shows that diversity has a significant negative relationship with ROA as it was before the control variable added to the model, and this shows that a percent increase in diverse will bring about a $44.78 \%$ decrease in ROA. Community, environment, and work did not show a significant relationship with ROA.

The $R$-square, which shows the extent to which the independent variables explain the model, has a value of $70.76 \%(0.7076)$. This means that the model explains about $70.76 \%$ of the variability in the ROA of the companies. The $P$ value of 0.000 of the $F$-test shows that the model is a good fit, and the overall significance of the model is subtle. CSR relationship has been examined by different researchers, and the coefficient of size as a control variable has varied, though most of the time, always found significant [159].

The result from the random effect model with the control variables can be specified as follows:

$$
\begin{aligned}
\mathrm{ROA}= & 0.7289-0.1771_{\mathrm{comm}}-0.4478_{\mathrm{div}} \\
& +0.2638_{\mathrm{env}}+0.2082_{\mathrm{wor}}-0.0322_{\text {size }}
\end{aligned}
$$

\begin{tabular}{|c|c|c|c|c|c|c|}
\hline \multirow[t]{2}{*}{ Variables } & \multicolumn{2}{|l|}{ Pooled OLS } & \multicolumn{2}{|l|}{ Fixed effects } & \multicolumn{2}{|c|}{ Random effects } \\
\hline & Coefficient & $P$ value & Coefficient & $P$ value & Coefficient & $P$ value \\
\hline Community & 0.2177328 & 0.253 & -0.1643036 & 0.564 & 0.1082614 & 0.600 \\
\hline Diverse & -0.2837918 & 0.236 & -1.293394 & 0.071 & -0.4526823 & 0.216 \\
\hline Environment & $-0.673637^{*}$ & 0.013 & -0.3812424 & 0.419 & -0.6360807 & 0.069 \\
\hline Work & 0.2768203 & 0.236 & 0.1379779 & 0.759 & 0.3988235 & 0.203 \\
\hline Constant & 0.3561 & & 1.1281 & & 0.4138 & \\
\hline$R$-squared & 0.2506 & & 0.0013 & & 0.1976 & \\
\hline$P$ value $(F)$ & 0.1122 & & 0.1696 & & 0.2156 & \\
\hline \multicolumn{7}{|l|}{ F-test } \\
\hline Chi-square & & & 2.55 & & & \\
\hline$P$ value & & & 0.0610 & & & \\
\hline \multicolumn{7}{|c|}{ Lagrange multiplier test } \\
\hline Chi-square & 0.94 & & & & & \\
\hline$P$ value & 0.1662 & & & & & \\
\hline
\end{tabular}

Table 5 Panel data analysis with ROE as the dependent variable 


\section{Dependent variable: returns of equity (ROE)}

Table 5 presents the result of the regression analysis using pooled OLS, fixed effect, and random effect model with ROE as the dependent variable. The number of companies examined is six, and the time period was 5 years.

The two-specification test shows that the pooled OLS is the most appropriate model for this analysis. The $R$-squared of 0.2506 indicates that the independent variables explain about $25.06 \%$ of the variability in the dependent variable ROE. The result also shows that there is a strong negative relationship between environment and ROE, while the result did not show a significant relationship between community, diverse, work, and ROE. The Pooled model can be specified below as follows with $\varepsilon$ representing the unexplained part of ROE:

Table 6 Pooled OLS with control variable (firm size)

\begin{tabular}{lcc}
\hline Pooled OLS & \multicolumn{2}{c}{ Effect of the control variable (size) } \\
\cline { 2 - 3 } Variables & Coefficient & P value \\
\hline Community & 0.1722218 & 0.361 \\
Diverse & -0.3096925 & 0.190 \\
Environment & -0.2206071 & 0.585 \\
Work & 0.1425493 & 0.561 \\
Size & -0.0189995 & 0.163 \\
Constant & 0.6561 & \\
R-square & 0.3103 & \\
F-test & & \\
Chi-square & 2.16 & \\
P value & 0.0927 & \\
\hline
\end{tabular}

The result is evaluated based on $95 \%$ level of significance

$$
\begin{aligned}
\mathrm{ROE}= & 0.3561+0.2177_{\mathrm{comm}}-0.2838_{\mathrm{div}} \\
& -0.6736_{\mathrm{env}}+0.2768_{\mathrm{wor}}
\end{aligned}
$$

The pooled OLS result with control for the size of the company shows that the size of the company is not statistically significant as it has a $P$ value of 0.163 . Also, the relationship between size and the ROE of firms exhibits a negative relationship, as shown in Table 6 . The result further indicates that community, diverse, environment, and work did not show a significant relationship with ROE.

The $R$-square value, which represents to what extent the independent variables, explains the model comes out with a value of 0.3103 . This means that the model explains about $31.03 \%$ of the variability in the ROE of the companies. The $P$ value of 0.0927 of the $F$-test shows that the model is not overall significant.

The result from the pooled OLS model with size as the control variables can be specified as follows:

$$
\begin{aligned}
\text { ROE }= & 0.6561+0.1722_{\text {comm }}-0.3097_{\mathrm{div}} \\
& -0.2206_{\mathrm{env}}+0.1425_{\mathrm{wor}}-0.0189_{\text {size }}
\end{aligned}
$$

\section{Dependent variable: EPS}

Table 7 shows the results obtained from the regression analysis between the independent variables, which are data, used to cover the CSR and the dependent variable represented by EPS. The panel analysis for the pooled, fixed, and the random effect is presented below without the control variable.

The fixed-effect model is the most appropriate model for this analysis, as shown in Table 7 by the specifica-

\begin{tabular}{|c|c|c|c|c|c|c|}
\hline \multirow[t]{2}{*}{ Variables } & \multicolumn{2}{|l|}{ Pooled OLS } & \multicolumn{2}{|c|}{ Fixed effects } & \multicolumn{2}{|c|}{ Random effects } \\
\hline & Coefficient & $P$ value & Coefficient & $P$ value & Coefficient & $P$ value \\
\hline Community & -102.1362 & 0.554 & -189.8624 & 0.289 & -58.63368 & 0.732 \\
\hline Diverse & 414.4794 & 0.064 & -1300.931 & 0.006 & 344.1367 & 0.119 \\
\hline Environment & 280.4711 & 0.233 & 199.2085 & 0.497 & 219.4481 & 0.352 \\
\hline Work & -136.3169 & 0.520 & -180.325 & 0.521 & -105.9302 & 0.623 \\
\hline Constant & -160.4673 & & 990.6312 & & -133.7672 & \\
\hline$R$-squared & 0.2412 & & 0.1658 & & 0.2380 & \\
\hline$P$ value $(F)$ & 0.1274 & & 0.0564 & & 0.2107 & \\
\hline \multicolumn{7}{|l|}{ F-test } \\
\hline Chi-square & & & 10.15 & & & \\
\hline$P$ value & & & 0.0001 & & & \\
\hline \multicolumn{7}{|c|}{ Lagrange multiplier test } \\
\hline Chi-square & 2.40 & & & & & \\
\hline$P$ value & 0.0605 & & & & & \\
\hline
\end{tabular}
tion test. $R$-squared of 0.1658 shows that the independent variables explain about $16.58 \%$ of the variability in the

Table 7 Panel data analysis results with EPS as the dependent variable

The result is evaluated based on $95 \%$ level of significance 
dependent variable EPS. Furthermore, the result shows that there is a strong negative relationship between diversity and EPS, while the result did not show a significant relationship between community, environment, work, and EPS. The fixed-effect model can be specified below as follows with $\varepsilon$ explaining the part of the model not captured by the independent variables:

$$
\begin{aligned}
\mathrm{EPS}= & 990.6312-189.8624_{\mathrm{comm}}-1300.931_{\mathrm{div}} \\
& +199.2085_{\mathrm{env}}-180.325_{\mathrm{wor}}
\end{aligned}
$$

In adding the control variable, which is the size of the company, the result shows that firm size has an insignificant statistical $P$ value of 0.639 . However, the relationship between size and the EPS of firms shows a positive relationship, as shown in Table 8. The result further shows that diversity has a significant negative relationship with EPS as it was before the control variable added to the model. Lastly, community, environment, and work did show an insignificant relationship with EPS.

The $R$-square, which shows the extent to which the independent variables explain the model, has a value of 0.1100 . This means that the model explains about $11 \%$ of the variability in the EPS of the companies. The $P$ value of 0.1014 of the $F$-test shows that the overall model significance of the model is not strong enough.

The result from the fixed effect model with the control variables can be specified as follows:

$$
\begin{aligned}
\mathrm{EPS}= & 541.364-189.1974_{\mathrm{comm}}-1381.078_{\mathrm{div}} \\
& +189.5613_{\mathrm{env}}-196.7573_{\mathrm{wor}}+26.8315_{\mathrm{size}}
\end{aligned}
$$

\section{Testing for multicollinearity}

As presented in Table 9, the multicollinearity result, which based on the rule of thumb, is that if VIF with a value less than five but must not be more than value is

Table 8 Fixed effect with control variable (firm size)

\begin{tabular}{lcc}
\hline Fixed effect & \multicolumn{2}{l}{$\begin{array}{l}\text { Effect of the control variable (firm } \\
\text { size) }\end{array}$} \\
\cline { 2 - 3 } Variables & Coefficient & P value \\
\hline Community & -189.1974 & 0.300 \\
Diverse & -1381.078 & 0.008 \\
Environment & 189.5613 & 0.527 \\
Work & -196.7573 & 0.496 \\
Size & 26.83146 & 0.639 \\
Constant & 541.364 & \\
R-square & 0.1100 & \\
F-test & & \\
Chi-square & 2.17 & \\
P value & 0.1014 & \\
\hline
\end{tabular}

The result is evaluated based on a $95 \%$ level of significance
Table 9 Testing for multicollinearity based on VIF and Tolerance

\begin{tabular}{lll}
\hline Variable & Collinearity tolerance & Statistics VIF \\
\hline Work & 9.77 & 0.1023 \\
Environment & 5.85 & 0.1709 \\
Diverse & 4.80 & 0.2082 \\
Community & 4.25 & 0.2355 \\
Size & 3.17 & 0.3153 \\
\hline
\end{tabular}

The dependent variables for the test are ROA, ROE and EPS

10. The result shows that there were no multicollinearity problems with the independent variables. The work variable has the highest collinearity, but however, it is not more than 10. The values of all the VIF are still within the acceptable level of not more than 10.

\section{Discussion \\ CSR and FP relation}

Table 10 depicts a summary of the hypothesis tested in this study. The subsequent part of this section discusses in detail the CSR and FP relationship of this research.

Relationship between community and FP (ROE, ROA and EPS) Based on the findings of the study, H1, H2 and H3 were rejected, meaning that there is no significant relationship between CSR (community) and FP (ROE, ROA and EPS). This finding contradicts previous literature and there can be several possible reasons for that.

Firstly, CSR is a novel idea that "creating shared value," which is proposed by Porter and Kramer [69] in the HBR. The basic idea behind this principle is that an organization generates economic benefit by way of creating value for the society, but [164] stated that this norm is not valid. The reason for the invalidation of Porter and Kramer [69] preposition is because CSR is multifaceted, so just by philanthropic giving the shared value cannot achieve, rather a company should develop a clear CSR program that aligns with the business purpose. In line with this reasoning [175] stated that in the Maldives only a few companies have formal CSR strategy. Thus, just by donating money to the community by the Maldives, public companies may not increase the FP of the enterprise. Furthermore, [164] suggested organization should run planned coordinated CSR program, otherwise that may not bring any benefits to the company, in line with this rational [175] stated that companies in the Maldives conduct CSR activities more "informal and unplanned" ways and indicated that in the Maldives only $23 \%$ of companies 
Table 10 Summary of the hypotheses tested

\begin{tabular}{|c|c|c|c|c|}
\hline Hypothesis number & Relationship between two variables & Expected relationship & Result ( $P$ Value) & Outcome \\
\hline $\mathrm{H} 1$ & Community and ROE & Positive & 0.253 & Not supported \\
\hline $\mathrm{H} 2$ & Community and ROA & Positive & $0.711(-)$ & Not supported \\
\hline H3 & Community and EPS & Positive & $0.289(-)$ & Not supported \\
\hline $\mathrm{H} 4$ & Environmental and ROE & Positive & $0.013(-)$ & Supported \\
\hline H5 & Environmental and ROA & Positive & $0.321(-)$ & Not supported \\
\hline H6 & Environmental and EPS & Positive & 0.497 & Not supported \\
\hline H7 & Workplace and ROE & Positive & 0.236 & Not supported \\
\hline H8 & Workplace and ROA & Positive & 0.065 & Not supported \\
\hline H9 & Workplace and EPS & Positive & $0.521(-)$ & Not supported \\
\hline $\mathrm{H} 10$ & Diverse and ROE & Positive & $0.236(-)$ & Not supported \\
\hline $\mathrm{H} 11$ & Diverse and $\mathrm{ROA}$ & Positive & $0.044(-)$ & Supported \\
\hline $\mathrm{H} 12$ & Diverse and EPS & Positive & $0.006(-)$ & Supported \\
\hline H13-01 & ROE and firm size & Positive & $0.163(-)$ & Not supported \\
\hline $\mathrm{H} 13-02$ & ROA and firm size & Positive & $0.000(-)$ & Supported \\
\hline $\mathrm{H} 13-03$ & EPS and firm size & Positive & 0.639 & Not supported \\
\hline
\end{tabular}

consult relevant parties when planning CSR programs for the upcoming years hence, that might be the reason for insignificant results of this study.

Secondly, CSR initiatives vary from industry to industry [31]. In line with this argument, [66] stress "consumer service" industries such as banking, general retail, and insurance, etc., companies focus more on community engagement CSR programs. Conversely, "heavy" industries such as oil and gas refining and utility, etc. companies concentrate more on natural environment CSR programs than community involvement programs. Hence, the CSR initiatives undertaken by Maldives public companies might have overlooked the industry it operates when developing CSR programs. That might be the reason for the insignificant result of this study.

Thirdly, McLennan and Banks [162] stated that understanding the need of the local community framing CSR community development programs is a necessity because of the heterogeneous nature of the city. Eweje [52] points out the main reason for the failure of the CSR community development program is due to not addressing the social and environmental issues that are intended to solve and lack of trust community have on the company. In the case of Maldives, some of the public company community development CSR programs politically driven. Shareef et al. [175] affirm in the Maldives, most of the prominent local entrepreneur is politically motivated. Hence, the CSR initiatives undertaken by Maldives public companies might be politically driven, conduct CSR community development programs without assessing needs, and unfulfilled promise leads to mistrust between companies and community might be the reason for the insignificant result of this study.

\section{Relationship between environment and FP (ROE, ROA and EPS)}

Based on the findings of the study, H4 was accepted, meaning that there is a significant relationship between CSR (environment) and FP (ROE), but the results found are negative. This finding is in line with $[116,159]$. These scholars argue that when the firm engages in disclosing environmental-related CSR programs leads to negative financial performance, and the reason is the cost involve in such programs outweighs the cost than the benefits it brings to the company. Shareef et al. [175] affirms that in the Maldives, only $18 \%$ of businesses people believe cost reduce when the organization engages in CSR (environment) related activities.

Conversely, based on the findings of the study $\mathrm{H} 5$ and H6 were rejected, meaning that there is no significant relationship between CSR (environment) and FP (ROA and EPS). Therefore, this study finding contradicts previous other literature and there can be several possible reasons for that.

Firstly, Maldives is a developing country, and the state regulates most of the corporate-related things as the caretaker of the country. Therefore, most of the things related to environment protection such as air pollution, biodiversity, carbon emission, deforestation, and energy efficiency strictly governed through laws and regulations rather than business-driven initiatives. According to [134] CSR as a voluntary contribution and does not require laws to follow. But in developing countries like the Maldives, CSR is more government-driven than business-driven. As discussed earlier, a caretaker of the society government has enacted and made a mandatory requirement for business by law that may be related to 
the environment. Hence, stakeholders in the Maldives do not consider mandatory CSR disclosure as real CSR initiatives. Due to that, the improved financial benefits may not be evident in environment-related affairs.

Secondly, the so-called "environmental investors" are still the minority in the investor's markets [7]. A country like the Maldives, where CSR is at its infancy stage, may not have "environmental investors." In line with this reasoning [175] stated that CSR in the Maldives is "mediocre" and documented that environmental protection and ethical standards are CSR practices of business, but customers do not consider environmental protection and ethical standards are CSR practices that local companies should adhere. Therefore, in the Maldives context, "environmental investors" dilemma might not be true due to that in the short term, firms may not gain any financial benefits.

Thirdly, CSR disclosure between the firms, especially the Industry, which it operates, leads to more CSR disclosure [22, 60]. In line with this thinking [190], argue that companies that negatively affect the environment tend to disclose more compare with other Industry. In line with this reasoning, [175] suggest that the primary focus of tourism companies in the Maldives focuses on environment protection than any other aspect of CSR. The other business owners belong to other Industries focus their CSR activities on another aspect, such as community development. In line with this thinking, most of the sample companies listed in the MSE not regarded as a controversial Industry hence financial gain not materialized.

\section{Relationship between workplace and FP (ROE, ROA and EPS)}

Based on the findings of the study, H7, H8 and H9 rejected, meaning that there is no significant relationship between CSR (workplace) and FP (ROE, ROA and EPS). This finding is in line with $[93,155]$, which stated workplace and FP have no significant relation. On the other hand, this finding contradicts previous literature and there can be several possible reasons for that.

Firstly, in the academic literature, CSR and workplace (employees) show a very positive picture. CSR-related programmed can reduce labor turnover, created a sense of belongingness, attract more talented staff, and be more committed to their work. Conversely Brieger et al. [162] advocated that the dark side of the CSR has not been explored. CSR companies might do some window dressing to portray to the public that the company is a socially responsible company at the expense of employees [7]. For example, in the Maldives, some public companies' MD salary is very high, but the employee's salary was not competitive. Previous literature shows that socially responsible reputed companies' wages are significantly low [138]. Furthermore, Brieger et al. [162] founds that working in CSR committed company may lead to employee work addiction, which may harm the well-being of the worker, family, and friends. Due to the stated reasons, employees working in public companies in the Maldives may not have considered CSR disclosure is vital.

Secondly, [175] affirms that in the Maldives, employees are the major second most frequently target group of CSR activities. They suggest that companies provide medical expenses coverage, different training programs, recreational activities, and some financial assistance programs as well, and these things lead to workers' loyalty to boost by $52 \%$. The single most striking observation that emerges from the study shows no significant relationship, and this is an alarming result. A likely reason is that the investment made by Maldivian public companies on human capital outweighs the FP measured during the study period. There can be a possibility that Maldivian public companies have taken substantial steps toward the development of the workforce in their organization. However, the organization may not have reaped the benefits in the form of financial gain.

Thirdly, CSR is considered as "two-way street" Tsavdaridou and Metaxas [183] that mutually benefits both (stakeholders and business) parties. Contrary to this line of reasoning [175] suggest that in the Maldives, CSR is perceived to be "one-way street" rather than "two-way street." Further, documented that in Maldives organization does not expect anything in return on CSR activities, and if the company expects anything in return, then it is considered as the outside realm of CSR initiatives. This might be because the Maldives is $100 \%$ Muslim country, this perception comes from the Islamic religion of almsgiving (Zakat or Sadaquath), which advocates donation to vulnerable people, and by helping poor people, we should not expect material benefit return in this world.

Fourthly, sometimes, the entrepreneur may not be able to reap the benefits of CSR initiatives due to a lack of awareness of CSR among the stakeholders. This line of thinking supported by [175] posit that in the Maldives one of the most significant barriers in implementing and institutionalizing CSR within business is due to lack of awareness among the public, and it noted that $50 \%$ of the people believe that in the Maldives the main barrier in implementing CSR initiatives is due to lack of awareness.

\section{Relationship between diverse and FP (ROE, ROA and EPS)}

Based on the findings of the study $\mathrm{H} 11$ and $\mathrm{H} 12$ were accepted, meaning that there is a significant relationship between CSR (diverse) and FP (ROA and EPS), but the results found are negative. This finding is in line with [6, 103] posited that diversity leads to negative employee productivity and performance. As stated earlier, this 
study found a significant relationship between CSR (environment) and FP (ROA and EPS), but the results found are negative, and there can be several possible reasons for that.

Firstly, when there is a different ethnic group within the company leads the worker to indulge in disagreements that may not directly relate to their work; hence, it may lead to conflicts between the employees, and in the end, company productivity goes down. For example, the Maldivian worker and Sri Lankan worker may argue on the religious differences among them. In line with this thinking, [75] stated a deep level of divergences between the groups could lead to a negative impact on organizational performance. Furthermore, [127] suggests that interpersonal deviations arise between the employees may lead to a negative emotion that may detrimental to organizational productivity.

Secondly, the use of emigrant workers remains widespread due to a lack of skilled labor force [1]. According to [131], the number of emigrant workers has increased by $188 \%$ between, 2000 to 2011 and estimated that, on average, a $5 \%$ increase would be there in every alternative year. These numbers show alarming figures indicating the different nationals working in various companies in the Maldives. Hence, companies' workforce diversity can have a considerable impact on organizational performance. Most of the time, in Maldives expatriate workers, does the odd job in the construction industry Maldivian considers those workers as very inferior and discriminates their workers [151]. This might be the case in public companies; hence, if the employees discriminated, then it leads to unhappy work condition may result in the productivity of the companies. In the same vein, [187] posit if employees are not happy and if they are discriminated based on their cultural differences, it will lead to low morale in the working environment and dissatisfy and at the end it leads to negative performance and affects the productivity of the organization.

Thirdly, a diverse workforce leads to employee turnover and absenteeism to go up, which leads to lower productivity of the organizations [26]. Leonard and Levine [110] acknowledged if employees are isolated based on cultural differences, age or gender from coworkers may increase labor turnover. In line with this [198] conceive that diversity leads to negative dynamics such as stereotyping, cultural classes, and ethnocentrism, and these negative dynamics lead to employee turnover and absenteeism. This might be the case in public companies in the Maldives. Hence, if diversity is overlooked or not adequately handled by the top management, it may detract the productivity of the companies.

Based on the findings of this study, H10 was rejected, meaning that there is no significant relationship between
CSR (diverse) and FP (ROE). Therefore, this finding is in line with scholars that argue on diversity, and organizational performance has no relation. For example, $[6,103$, 126] found that ethnicity diversity has no significant relation with innovation within an organization.

Conversely there is a large volume of published studies describing that diversity leads to improve financial performance $[9,115]$. As stated earlier, this study found no significant relationship between CSR (diverse) and FP (ROE), and there can be several possible reasons for that.

Firstly, according to the corporate governance code (clause 1.6(a)(v)(vi)) of Maldives, all public company boards should have a $30 \%$ representation of women [7]. But the samples taken for this study except one company remaining five companies didn't strictly follow the corporate governance code accordingly. It found that BML board have $33 \%$ of female, STO has $14 \%$ of female, Dhirague has 14\%, MTDC has 22\% female, Amana Takaful have $0 \%$, and MTCC has $0 \%$ female representation. According to [154] board, diversity is not just a simple "number game." Having the right mix of gender diversity in the boardroom leads to better financial performance [115]. Therefore, it is important for public companies in the Maldives to follow corporate governance code thoroughly so that in the future, that may improve the financial position of the company. Though currently public companies not following the CG code may not lead any adverse implication but maybe in the future, when the investors get to know the importance of diversity in the board may punish the companies.

Secondly, if the female directors appointed as "token," then it may not leads to a positive impact. According [94], the theory of "tokenism" if the group representation is less than $15 \%$, then it is considered as appointed as "token." If female directors appointed as "token", then it may lead to negative/no significant impact on organization performance. In the context of Maldives, the average female board representation of the six-sample company is $13 \%$. Therefore, it is safe to conclude that there is no significant statistical relationship between CSR (diversity) and FP (ROE) in the Maldivian plc context is due to "tokenism."

Thirdly, a report published by the Ministry of Environment indicated that lack of women in the decisionmaking level is a challenge that Maldives face in a time of advocacy of gender equality and empowerment [162]. In the same vein, the UNFPA Maldives bulletin indicated that only $25 \%$ of women work in the decision making level in the country. As stated earlier in the context of Maldives, the average female board representation of the six-sample company is $13 \%$, one of the possible reasons for that low representation can be due to the "glass ceiling." According to [50], the "glass ceiling" is a 
phenomenon where the promotion of certain people, especially women, doesn't go beyond a certain level in the hierarchy. In public companies, the highest top-ranking occupation considered as the board of directors' jobs, due to cultural thinking in the Maldives and the "glass ceiling" phenomena, sometimes, female employees do have difficulty climbing up in the leader of the hierarchy and be in the boardroom. Therefore, it is safe to conclude that there is no significant statistical relationship between CSR (diversity) and FP (ROE) in the Maldivian plc context is due to the "glass ceiling" phenomena.

\section{Control variable (firm size)}

Based on the findings of the study, H13-01 and H13-03 rejected, meaning control variable firm size is not a significant thing that affects organization CSR disclosure or FP. This result is consistent with [182] and Adeneye and Ahmed [2], and they posit that firm size cannot influence CSR or FP. Further, based on finding H13-02 accepted indicating firm size have a significant effect on ROA, this result consistent with $[33,141]$.

\section{Conclusion}

The main objective of this study is to find out the relationship between CSR initiatives to the financial performance of the public companies in the Maldives.

The results of this research broadly classified into three broad spectrums that are ROA, ROE, and EPS with CSR. ROA, as a dependent variable, result shows there is a robust negative relationship between diversity and ROA, while the result did not show a significant correlation between community, environment, work, and ROA. ROE, as a DV result also shows there is a robust negative relationship between environment and ROE while the result did not show a significant correlation between community, diverse, work, and ROE. Besides, to check the effect of the control variable on ROE, the results indicated the size of the company is not statistically significant. Similarly, the relationship between size and the ROE of firms exhibits a negative correlation. The result further shows Community, Diverse, Environment, and Work did not show a significant relationship with ROE. EPS, as a DV, the result shows there is a robust negative relationship between diversity and EPS, while the result did not show a significant correlation between community, environment, work, and EPS. Furthermore, to check the effect of the control variable on EPS, the results indicated that the size of the company has an insignificant. Nevertheless, the relationship between size and the EPS of firms shows a positive relationship. The result further indicates diversity has a significant negative correlation with EPS as it was before the control variable added to the model. Lastly, Community, Environment, and Work did show an insignificant relationship with EPS.

There are several vital contribution this study made; firstly, the CSR research done in the developing countries was very limited especially in the context of Maldives, In doing so, the results of this study suggest that public companies in the Maldives are practicing CSR, and companies are reporting CSR initiatives in the annual report of the companies. Secondly, this study has examined the relevance of different management theories that are developed in the field of CSR and tries to identify the association between different variables that affect CSR theories. This study confirms the importance of stakeholders' theory in understanding CSR in the Maldivian market. Thirdly, this research used panel data, that is widely been used in academia in order to check the relationship between CSR and FP [111, 180]. Therefore, this study used improved data methods in identifying the association between CSR and FP and documented that there is statistical significance between the CSR and FP of public limited companies in the Maldives. Fourthly, this study is one of its kind that has explored, the relationship between CSR and FP of listed companies in the Maldives, therefore, this study contributes existing body of knowledge as a reservoir hence in future this research work can be reference materials for researchers and students who wants to explore this subject matters in the future.

The empirical outcomes suggested in this research should be considered in the light of some constraint because no research is without limitation; hence, this study also has several limitations due to the methodology adopted by this study. Firstly, the major limitation of this study is the "CSR instrument" adopted by this research. Secondly, the sample size used in this study is six, and the time horizon of the study is 5 years from 2014 and 2018 due to limited companies listed on the stock exchange, and the small number of samples size might be the reason for negative results of this research. Therefore, generalizability of this research finding might not be applicable to all companies in the Maldives. Thirdly, to assess the CSR disclosure by the public companies in the Maldives, this research used the company annual report using the content analysis and to convert the qualitative data to quantitative data, the dichotomous process has been used to calculate each company CSR disclosure under each specific criterion identified in CSR framework. Since the primary documents used in measuring CSR is an annual report; therefore, the finding of this research largely depends on the quality of information presented in the annual report. Fourthly, the primary dependent variable of this study was FP, and the proxies of FP included as ROE, ROA, and EPS. This financial ratio calculated 
from the financial statement; hence, the reliability of this finding largely depends on the "true and fair" values presented in the financial statement.

Several suggestions can be given for the future researcher in making a more judgmental decision in making this research more meaningful. First is developing a "CSR instrument" for local context and testing the relationship between CSR and FP. Secondly, it includes more samples and extending the study duration may give more meaningful results. Further, this study purely used annual report in identifying CSR disclosure, future researcher advisable to used website information and standalone CSR report can also use that may get more meaningful results. Thirdly, this study focuses only public listed company in Maldives stock exchange; the future researcher can look into both public and private company, that may give more conclusive information related to CSR, and it can augment the external validity of the finding of this study, and also can used other advanced econometric technique that analyzes the relationship between CSR and FP such as continuous wavelet transformation (CWT) method proposed by (Kenourgios, Drakonaki and Dimitriou). Fourthly, it can include more variables or other different variables in both CSR and FP measurement and check the association between CSR and FP can augment the external validity of the finding of this study. Furthermore, different other control variables such as R and D, institutional ownership, and leverage can be used. Therefore, future work can include these variables and check the association between CSR and FP.

\section{Abbreviations \\ CSR: Corporate Social Responsibility; FP: Financial Performance; ROA: Return on Assets; ROE: Return on Equity; EPS: Earnings Per Share; OLS: Ordinary least- squares; FEM: Fixed Effect Model; REM: Random Effect Model; MTCC: Maldives Transport and Contracting Company; MTDC: Maldives Tourism Development Corporation; STO: State Trading Organization; BML: Bank of Maldives.}

\section{Acknowledgements}

Not applicable.

\section{Authors' contributions}

The paper was conceptualized by 'IS'; data extracted and contributed by 'IS'; formal analysis was contributed by 'IS'; investigation was contributed by 'IS'; methodology was contributed by 'IS'; validation was contributed by 'IS'; visualization was contributed by'IS'; writing —original draft—was contributed by 'IS'; writing — review and editing — was contributed by 'IS.' Author read and approved the final manuscript.

\section{Funding}

Not applicable.

Availability of data and materials

Yes.

\section{Declarations}

\section{Competing interests}

None.
Received: 23 October 2020 Accepted: 11 June 2021

Published: 16 August 2021

\section{References}

1. ADB (2015) Maldives overcoming the challenges of a small island state country diagnostic study. ADB, Manila

2. Adeneye YB, Ahmed M (2015) Corporate social responsibility \& company performance. J Bus Stud Q 7(1):151-166

3. Ajfei SM (2015) A content analysis of sustainability dimensions in annual reports. FIU electronic theses and dissertations, Florida, USA

4. Akbar A, Imdadullah M, Ullah MA, Aslam M (2011) Determinants of economic growth in asian countries: a panel data perspective. Pak J Soc Sci 31(1):145-157

5. Ali I et al (2010) Corporate social responsibility influences, employee commitment and organizational performance. Afr J Bus Manag 4(12):2796-2801

6. Ali M, Ng YL, Kulik CT (2014) Board age and gender diversity: a test of competing linear and curvilinear predictions. J Bus Ethics 125(3):497-512

7. Ali W (2014) Corporate social responsibility disclosure (CSRD): a case study of Pakistan. Doctoral dissertation, pp 1-451

8. Ambec S, Lanoie P (2008) Does it pay to be green? A systematic overview. Acad Manag Perspect 22:45-62

9. Assenga P, Aly DA, Hussainey K (2018) The impact of board characteristics on the financial performance of Tanzanian firms. Corp Gover Int J Bus Soc 18(6):1089-1106

10. Atiyah AR (2016) The relationship between the diversity of employees and organizational performance. Cross-Cult Manag J 18(2):151-163

11. Aupperle KE, Carroll AB, Hatfield JD (1985) An empirical investigation of the relationship between corporate social responsibility and profitability. Acad Manag J 28(2):446-463

12. Babiak K, Trendafilova S (2011) CSR and environmental responsibility: motives and pressures to adopt green management practices. Corp Soc Responsib Environ Manag 18(1):11-24

13. Baetschmann G, Staub K, Winkelmann R (2017) Consistent estimation of the fixed effects ordered logit model. J R Stat Soc Ser A (Stat Soc) 178(3):685-703

14. Bagh T et al (2017) The corporate social responsibility and firms'financial performance: evidence from financial sector of Pakistan. Int J Econ Financ 7(2):301-308

15. Barnett $L$ (2007) Stakeholder influence capacity and the variability of financial returns to corporate social responsibility. Acad Manag Rev 32(3):794-816

16. Berger $L$ (2018) Unconscious bias in the workplace: you can't afford to ignore it. https://www.forbes.com/sites/forbescoachescouncil/2018/ 03/23/unconscious-bias-in-the-workplace-you-cant-afford-to-ignoreit/\#729edd167660. Accessed 23 Aug 2019

17. Beurden PV, Gössling T (2008) The worth of values - a literature review on the relation between corporate social and financial performance. J Bus Ethics 82:407

18. Bhandari A, Javakhadze D (2017) Corporate social responsibility and capital allocation efficiency. J Corp Finan 43:354-377

19. Bhattacharya C, Sen R (2004) Doing better at doing good: when, why and how consumers respond to corporate social initiatives. Calif Manag Rev 47(1):9-24

20. Bouraoui K, Bensemmane S, Ohana M, Russo M (2019) Corporate social responsibility and employees' affective commitment A multiple mediation model. Manag Decis 57(1):152-167

21. Bowen HR (1953) Social responsibilities of the businessman. Harper, New York

22. Brammer S, Pavelin S (2006) Voluntary environmental disclosures by large UK companies. J Bus Finance Acc 33(7-8):1 168-1188

23. Brieger SA et al (2019) Too much of a good thing? On the relationship between CSR and employee work addiction. J Bus Ethics 17:1-19

24. Brønn PS, Vrioni AB (2001) Corporate social responsibility and causerelated marketing: an overview. Int J Adv 20(2):207-222

25. Burton BK, Farh J, Hegarty WH (2000) A cross cultural comparison of corporate social responsibility orientation: Hong Kong vs United States Students. Teach Bus Ethics 4:151-167 
26. Buttner E, Lowe B, Harris B (2010) Diversity climate impact on employee of color outcomes: does justice matter? Career Dev Int 15(3):239-258

27. Carroll AB (1999) Corporate social responsibility: evolution of a definitional construct. Bus Soc 38(3):268-295

28. Carroll AB, Shabana KM (2010) The business case for corporate social responsibility: a review of concepts, research and practice. Int J Manag Rev 12(1):85-105

29. Carroll AB (2016) Carroll's pyramid of CSR: taking another look. Int J Corp Soc Responsib 1(3):2-8

30. Carroll AB (1979) A three-dimensional conceptual model of corporate social performance. Acad Manag Rev 4(4):497-505

31. Casado B, Nicolau JL, Ruiz F, Sellers R (2014) Industry-specific effect of CSR initiatives: hotels and airlines. Kybernetes 43(3/4):547-564

32. CEC (2001) Promoting a European framework for Corporate Social Responsibility, pp 1-32

33. Chek IT, Mohamad ZZ, Yunus J, Norwani R (2013) Corporate social responsibility (CSR) disclosure in consumer products and plantation industry in Malaysia. Am Int J Contemp Res 3(5):118-125

34. Chen ZF, Hong C, Occa A (2019) How different CSR dimensions impact organization-employee relationships: the moderating role of CSRculture fit. Corp Commun Int J 24(1):63-78

35. Chetty S, Naidoo R, Seetharam Y (2015) The impact of corporate social responsibility on firms' financial performance in South Africa. Contemp Econ 9(2):193-214

36. Cho SJ, Chung CY, Young J (2019) Study on the relationship between CSR and financial performance. Sustainability 11(2):1-26

37. Cho H, Guidry P, Hageman M, Patten M (2012) Do actions speak louder than wordss? An empirical investigation of corporate environmental reputation. Acc Organ Soc 37(1):14-25

38. Choongo P (2017) A longitudinal study of the impact of corporate social responsibility on firm performance in SMEs in Zambia. Sustainability 9(8):1-19

39. Chuang SP, Huang SJ (2016) The effect of environmental corporate social responsibility on environmental performance and business competitiveness: the mediation of green information technology capital. J Bus Ethics 25:1-19

40. Clark S, Linzer S (2015) Should I use fixed or random effects? Polit Sci Res Methods 3(2):399-408

41. Cohen J (1960) A coefficient of agreement for nominal scales. Educ Psychol Meas 20(1):37-46

42. Crifo P, Diaye M-A, Pekovic S (2016) CSR related management practices and firm performance: an empirical analysis of the quantity-quality trade-off on French data. Int J Prod Econ 171(3):405-416

43. Cruz S, Vaduva S, Fotea I, Neagoie D (2015) Business ethics \& corporate social responsibility attitudes among SME leaders in Romania. In: Proceeding of the 9th international management conferance "management and innovation for competitive advantage". Bucharest , 2015. University of Bucharest Academy of Economic Studies

44. Dabic M et al (2016) Industry-specific CSR: analysis of 20 years of research. Eur Bus Rev 28(3):250-273

45. Dahlsrud A (2008) How corporate social responsibility is defined: an analysis of 37 definitions. Corp Soc Respons Environ Manag 15:1-13

46. Dartey-Baah K, Amponsah-Tawiah K (2011) Exploring the limits of Western Corporate Social Responsibility Theories in Africa. Int J Bus Soc Sci 2(18):126-137

47. Das L, Bhunia A (2016) The impact of CSR on firms' financial performance - a literature review. Am J Bus Econ Manag 4(4):66-74

48. Dawkins CE et al (2014) Corporate social responsibility and job choice intentions: a cross-cultural analysis. Bus Soc 35:1-35

49. Dhanesh GS (2014) CSR as organization-employee relationship management strategy: a case study of socially responsible information technology companies in India. Manag Commun Q 28(1):130-149

50. Ekadah W, Mboya J (2015) Effect of board gender diversity on the performance of commercial banks in Kenya. Eur Sci J 8(7):128-148

51. Esen E (2013) The influence of corporate social responsibility (CSR) activities on building corporate reputation. Int Bus Sustain Corp Soc Responsib 11:133-150

52. Eweje G (2007) Multinational oil companies' CSR initiatives in Nigeria. Managerial Law 49(5/6):218-235
53. Famiyeh S, Kwarteng A, Dadzie SA (2016) Corporate social responsibility and reputation: some empirical perspectives. J Glob Responsib 7(2):258-274

54. Fatma M, Khan I, Rahman Z (2018) Striving for legitimacy through CSR: an exploration of employees responses in controversial industry sector. Soc Responsib J

55. Feng M, Wang X, Kreuze Y (2017) Corporate social responsibility and firm financial performance: comparison analyses across industries and CSR categories. Am J Bus 32(3-4):106-133

56. Fitch HG (1976) Achieving corporate social responsibility. Acad Manag Rev 1(1):38-46

57. Fridson F, Alvarez Z (2011) Financial statement analysis: a practitioner's guide, 4th edn. Wiley, New York

58. Friedman A (1970) The social responsibility of business is to increase its profits. The New York times magazine

59. Galant A, Cadez S (2017) Corporate social responsibility and financial performance relationship: a review of measurement approaches. Econ Res 30(1):676-693

60. Gamerschlag R, Möller K, Verbeeten F (2011) Determinants of voluntary CSR disclosure: empirical evidence from Germany. RMS 5(2-3):233-262

61. Garai S (2017) Impact of corporate social responsibility on firm's financial performance with a special reference of RIL. Int J Appl Res 3(1):38-41

62. Gatimbu KK, Wabwire JM (2016) Effect of corporate environmental disclosure on financial performance of firms listed at Nairobi Securities Exchange, Kenya. Int J Sustain Manag Inf Technol 2(1):1-6

63. Geringer JM, Beamish PW, DaCosta RC (1989) Diversification Strategy and Internationalization: implications for MNE Performance. Strateg Manag J 10(2):109-119

64. Gielissen B (2011) Why do consumers buy socially responsible products? Int J Bus Soc Sci 2(3):21-35

65. Glavas A, Godwin LN (2013) Is the perception of 'goodness' good enough? Exploring the relationship between perceived corporate social responsibility and employee organizational identification. J Bus Ethics 114(1):15-27

66. Godfrey PC, Hatch NW, Hansen JM (2010) Toward a general theory of CSRs: the roles of beneficence, profitability, insurance, and industry heterogeneity. Bus Soc 49(2):316-344

67. Green T, Peloza J (2011) How does corporate social responsibility create value for consumers? J Consum Mark 28(1):48-56

68. Greening DW, Turban DB (2000) Corporate social performance as a competitive advantage in attracting a quality workforce. Bus Soc 39:3

69. Gross R, Holland B (2011) Corporate social responsibility and employee engagement: making the connection. Mandrake

70. Guthrie J, Abeysekera I (2006) Content analysis of social, environmental reporting: what is new? J Hum Resour Cost Acc 10(2):114-126

71. Haar BT, Keune M (2014) One step forward or more window-dressing? A legal analysis of recent csr initiatives in the garment industry in Bangladesh. Int J Comp Lab Law Ind Relat 30(1):5-25

72. Hamidu AA, Haron HM, Amran A (2015) Corporate social responsibility: a review on definitions, core characteristics and theoretical perspectives. Mediterr J Soc Sci 6(4):83-95

73. Hansen SD et al (2011) Corporate social responsibility and the benefits of employee trust: a cross-disciplinary perspective. J Bus Ethics 102(1):29-45

74. Harris EE (2014) The impact of board diversity and expertise on nonprofit performance. Nonprofit Manag Leadersh 25(2):113-130

75. Harrison A, Price H, Bell P (1998) Beyond relational demography: time and the effects of surface- and deep-level diversity on work group cohesion. Acad Manag J 41(1):96-107

76. Henriques I, Sadorsky P (1996) The determinants of an environmentally responsive firm: an empirical approach. J Environ Econ Manag 30(3):381-395

77. Hinson RE, Agbleze S, Kuada J (2013) Perspectives on corporate social responsibility (CSR) \& employers attractiveness. In: 14th IAABD annual conference, 2013. GIMPA ACCRA

78. Hirigoyen R, Rehm P (2015) Relationships between corporate social responsibility and financial performance: what is the causality? J Bus Manag 4(1):18-43 
79. Hohnen R (2007) Corporate social responsibility: an implementation guide for business. International Institute for Sustainable Development, Winnipeg, Canada

80. Hong H, Kacperczyk M (2009) The price of sin: the effects of social norms on markets. J Financ Econ 93(1):15-36

81. Hopkins M (2003) The planetary bargain: corporate social responsibility matters. Routledge, London

82. Imai K, Kim IS (2019) When should we use unit fixed effects regression models for causal inference with longitudinal data? Am J Polit Sci 63(2):467-490

83. Isanzu J, Fengju X (2016) Impact of corporate social responsibility on firm's financial performance: the Tanzanian perspective. J Innov Sustain $7(1): 18-27$

84. Iwata J, Okada X (2011) How does environmental performance affect financial performance? Evidence from Japanese manufacturing firms. Ecol Econ 70(9):1691-1700

85. Jacobs W, Singhal R, Subramanian S (2010) An empirical investigation of environmental performance and the market value of the firm. J Oper Manag 28(5):430-441

86. Javed M, Rashid MA, Hussain G, Ali HY (2020) The effects of corporate social responsibility on corporate reputation and firm financial performance: moderating role of responsible leadership. Corp Soc Responsib Environ Manag 27(3):1395-1409

87. Jehn KA, Northcraft GB, Neale MA (1999) Why differences make a difference: a field study of diversity, conflict, and performance in workgroups. Adm Sci Q 44(4):741-763

88. Jensen C, Meckling H (1976) Theory of the firm: Managerial behavior, agency costs and ownership structure. J Financ Econ 3(4):305-360

89. Jo H, Na H (2012) Does CSR reduce firm risk? Evidence from controversial industry sectors. J Bus Ethics 110(4):441-456

90. Joecks J, Pull K, Vetter K (2013) Gender diversity in the boardroom and firm performance: what exactly constitutes a "critical mass?" J Bus Ethics 118(1):61-72

91. Jones R (1980) Corporate social responsibility revisited, redefined. Calif Manag Rev 22(3):59-67

92. Jones A, Willness S, Madey R (2014) Why are job seekers attracted by corporate social performance? experimental and field tests of three signal-based mechanisms. Acad Manag J 57(2):383-404

93. Jung H-J, Kim D-O (2016) Good neighbors but bad employers: two faces of corporate social responsibility programs. J Bus Ethics 138(2):295-310

94. Kanter M (1977) Men and women of the corporation. New York, USA

95. Kesto DA (2017) The impact of corporate social responsibility practices on financial performance of banking sector in Ethiopia. Glob J Manag Bus Res 17(1):29-44

96. Kenourgios D, Drakonaki E, Dimitriou D (2019) ECB's unconventional monetary policy and cross-financial-market correlation dynamics. N A J Econ Finance 50:101045

97. Khan R (2005) Exploring the concept of sustainability in emerging markets: evidences from the Indian pharmaceutical industry. Oikos 1-14

98. Khojastehpour M, Johns R (2014) The effect of environmental CSR issues on corporate/brand reputation and corporate profitability. Eur Bus Rev 26(4):330-339

99. Kiliç R (2016) Online corporate social responsibility (CSR) disclosure in the banking industry Evidence from Turkey. Int J Bank Market 34(4):550-569

100. Kim Y, Brodhag S, Mebratu D (2014) Corporate social responsibility driven innovation. Innov Eur J Soc Sci Res 27(2):175-196

101. Krippendorff K (2012) Content analysis: an introduction to its methodology. SAGE Publications, New York

102. Krüger $P$ (2015) Corporate goodness and shareholder wealth. J Financ Econ 115(2):304-329

103. Kunze F, Boehm A, Bruch H (2013) Organizational performance consequences of age diversity: inspecting the role of diversity-friendly HR policies and top managers' negative age stereotypes. J Manag Stud 50(3):413-442

104. Kwanbo R (2011) An assessment of the effectiveness of social disclosure on earnings per share in Nigerian Public Corporations. World J Soc Sci 1(1):86-106
105. Lahouel BB, Zaied YB, Song Y, Yang GL (2020) Corporate social performance and financial performance relationship: a data envelopment analysis approach without explicit input. Finance Res Lett 69:101656

106. Leal Fa, Pasola V (2003) Using environmental management systems to increase firms' competitiveness. Corp Soc Responsib Environ Manag 10(2):101-110

107. Lee EM, Park SY, Lee HJ (2013) Employee perception of CSR activities: its antecedents and consequences. J Bus Res 66(1):1716-1724

108. Lee J, Graves S, Waddock S (2018) Doing good does not preclude doing well: corporate responsibility and financial performance. Soc Responsib J 14(4):764-781

109. Lee, et al (2018) Do a company's sincere intentions with CSR initiatives matter to employees? A comparison of customer-related and employee-related CSR initiatives. J Glob Responsib 9(4):355-371

110. Leonard S, Levine I (2006) The effect of diversity on turnover: a large case study. ILR Rev 59(4):547-572

111. Lin WL, Ho JA, Sambasivan M (2019) Impact of corporate political activity on the relationship between corporate social responsibility and financial performance: a dynamic panel data approach. Sustainability 11(1):60

112. Lis A (2012) The relevance of corporate social responsibility for a sustainable human resource management: an analysis of organizational attractiveness as a determinant in employees' selection of a (potential) employer. Manag Revue 22(3):279-295

113. Llach J, Marimon V, Alonso-Almeida MDM (2014) A closer look at the 'global reporting initiative' sustainability reporting as a tool to implement environmental and social policies: a worldwide sector analysis. Corp Responsib Environ Manag 21(6):318-335

114. Lorenzo R, Reeves M (2018) How and where diversity drives financial performance. Harvard Bus Rev 30:1-5

115. Loukil N, Yousfi O, Yerbanga R (2019) Does gender diversity on boards influence stock market liquidity? Empirical evidence from the French market. Corp Govern 19(4):669-703

116. Lu W, Taylor ME (2018) A study of the relationships among environmental performance, environmental disclosure, and financial performance. Asian Rev Acc 26(1):107-130

117. Luce RA, Barber AE, Hillman A (2001) Good deeds and misdeeds: a mediated model of the effect of corporate social performance on organizational attractiveness. Bus Soc 40(4):397-415

118. Madugba JU, Okpara MC (2016) Impact of corporate social responsibility on financial performance: evidence from listed banks in Nigeria. Expert J Finance 4:1-9

119. Mahoney L, Roberts W (2007) Corporate social performance, financial performance and institutional ownership in Canadian firms. Acc Forum 31(3):233-253

120. Makhdoomi M, Nika FA (2018) Workforce diversity and organizational performance - a review. Int J Enhanc Res Manag Comput Appl 7(3):571-576

121. Maqbool S, Bakr A (2019) The curvilinear relationship between corporate social performance and financial performance: evidence from Indian companies. J Glob Responsib 10(1):87-100

122. Maqbool S, Zameer MN (2018) Corporate social responsibility and financial performance: an empirical analysis of Indian banks. Future Bus J 4(1):84-93

123. Margolis JD, Elfenbein HA, Walsh JP (2009) Does it pay to be good and does it matter? A meta-analysis of the relationship between corporate social and financial performance. SSRN, pp 1-68

124. Marin X, Ruiz S, Rubio D (2008) The role of identity salience in the effects of corporate social responsibility on consumer behavior. J Bus Ethics 84(1):65-78

125. Marin L, Ruiz S (2007) "I need you too!" corporate identity attractiveness for consumers and the role of social responsibility. J Bus Ethics 71(1):245-260

126. Marinova J, Plantenga J, Remery H (2016) Gender diversity and firm performance: evidence from Dutch and Danish boardrooms. Int J Hum Resour Manag 27(15):1777-1790

127. Martin GC (2014) The effects of cultural diversity in the workplace. J Divers Manag 9(2):89-92 
128. McLennan L, Banks B (2019) Reversing the lens: why corporate social responsibility is not community development. Corp Soc Responsib Environ Manag 26(1):117-126

129. Melo A, Morgado G (2012) Corporate reputation: a combination of social responsibility and industry. Corp Soc Responsib Environ Manag 19(1):11-31

130. Milne A, Adler B (1999) Exploring the reliability of social and environmental disclosures content analysis. Acc Audit Acc J 12(2):237-256

131. Mohamed X (2013) The expatriate workforce: boon or bane? Q Econ Bull 12:13-20

132. Mohr A, Webb DJ, Harris E (2001) Do consumers expect companies to be socially responsible? The impact of corporate social responsibility on buying behavior. J Consum Aff 35(1):45-72

133. Mohr LA, Webb DJ (2005) The effects of corporate social responsibility and price on consumer responses. J Consum Aff 39(1):121-147

134. Moon D (2002) The social responsibility of business and new governance. Govern Opposit 37(3):385-408

135. Nassivera K et al (2017) Willingness to pay for organic cotton: Consumer responsiveness to a corporate social responsibility initiative. Br Food J 119(8):1815-1825

136. Neuendorf KA (2002) The content analysis guidebook. Sage Publications, Thousand Oaks

137. Nollet J, Filis K, Mitrokostas M (2015) Corporate social responsibility and financial performance: a non-linear and disaggregated approach. Econ Model 25:1-8

138. Nyborg K, Zhang T (2013) Is corporate social responsibility associated with lower wages? Environ Resour Econ 55(1):107-117

139. Nyeadi S, Ibrahim S, Sare C (2018) Corporate social responsibility and financial performance nexus: empirical evidence from South African listed firms. J Glob Responsib 9(3):301-328

140. Öberseder M, Schlegelmilch BB, Gruber V (2011) "Why don't consumers care about CSR?": A qualitative study exploring the role of CSR in consumption decisions. J Bus Ethics 104(4):449-460

141. Ofori F, S-Darko D, Nyuur B (2014) Corporate social responsibility and financial performance: fact or fiction? A look at Ghanaian banks. Acta Commer 14(1):1-11

142. Orlitzky W, Schmidt J, Rynes D (2003) Corporate social and financial performance: a meta-analysis. Organ Stud 24(3):403-441

143. Orlitzky J (2015) The politics of corporate social responsibility or: why Milton Friedman has been right all along. Ann Soc Responsib 1(1):5-29

144. Orlitzky M, Benjamin D (2001) Corporate social performance and firm risk: a meta-analytic review. Bus Soc 40(4):369-396

145. Patrick HA, Kumar A (2012) Managing workplace diversity: issues and challenges. SAGE Open 2(2):1-15

146. Peloza J (2009) The challenge of measuring financial impacts from investments in corporate social performance. J Manag 35(6):1518-1541

147. Peloza J (2006) Using corporate social responsibility as insurance for financial performance. Calif Manag Rev 48(2):52-72

148. Pérez A, Del-Bosque A (2016) The stakeholder management theory of CSR: A multidimensional approach in understanding customer identifcation and satisfaction. Int J Bank Mark 34(5):731-751

149. Perryman A, Fernando D, Tripathy A (2016) Do gender differences persist? An examination of gender diversity on firm performance, risk, and executive compensation. J Bus Res 69(2):579-586

150. Petkevičienè Š (2015) CSR reasons, practices and impact to corporate reputation. Soc Behav Sci 213(1):503-508

151. Plewa (2018) Migration in Maldives: a country profile 2018. International Organization for Migration.

152. Podestà A (2002) Recent developments in quantitative comparative methodology: the case of pooled time series cross-section analysis. DSS Pap SOC 3(2):5-44

153. Porter ME, Kramer MR (2011) Creating shared value. Harvard Bus Rev 89(1/2):62-77

154. Post C, Byron D (2015) Women on boards and firm financial performance: a meta-analysis. Acad Manag J 58(5):1546-1571

155. Pradhan X (2016) Impact of corporate social responsibility intensity on corporate reputation and Financial performance of Indian firms. Bus Theory Pract 17(4):371-380

156. Pratihari K, Uzma X (2018) CSR and corporate branding effect on brand loyalty: a study on Indian banking industry. J Prod Brand Manag 27(1):57-78
157. Preston LE, O'Bannon DP (1997) The corporate social-financial performance relationship: a typology and analysis. Bus Soc 36(4):419-429

158. Prieto ABT, Shin H, Lee Y, Lee CW (2020) Relationship among CSR initiatives and financial and non-financial corporate performance in the ecuadorian banking environment. Sustainability 12(4):1621

159. Qian (2012) Revisiting the link between environmental performance and financial performance: who cares about private companies? Govern Sustain 1-25

160. Rahdari H, Rostamya AA (2015) Designing a general set of sustainability indicators at the corporate level. J Clean Prod 108(Part A):757-771

161. Rahman S (2011) Evaluation of definitions: ten dimensions of corporate social responsibility. World Rev Bus Res 1(1):166-176

162. Rahman (2019) Communication strategy and action plan 2019-2023. Male': Ministry of Environment Ministry of Environment

163. Rahmawati D, Honggowati A, Supriyono A (2014) The effect of corporate social responsibility on financial performance with real manipulation as a moderating variable. Int J Manag Econ Soc Sci 3(2):59-78

164. Rangan VK, Chase L, Karim S (2015) The truth about CSR. Harv Bus Rev 93(1/2):40-49

165. Rashid MZ, Ibrahim S (2002) Executive and management attitudes towards corporate social responsibility in Malaysia. Corp Gov 2(4):10-16

166. Rashid RNA, Khalid A, Rahman NIA (2015) Environmental corporate social responsibility (ECSR): exploring its influence on customer loyalty. Procedia Econ Finance 31(1):705-713

167. Raza X, llyas I, Rauf R, Qamar Z (2012) Relationship between Corporate Social Responsibility (CSR) and Corporate Financial Performance (CFP): literature review approach. Elixir Int J 46:8404-8409

168. Russo S, Fouts D (1997) A resource-based perspective on corporate environmental performance and profitability. Acad Manag J 40(3):534-559

169. Rutledge R, Karim X, Aleksanyan R, Wu S (2014) An examination of the relationship between corporate social responsibility and financial performance: the case of Chinese state-owned enterprises. Acc Environ More Talk Little Progress 5:1-22

170. Saharan DS, Singh MS (2018) Impact of consumer expectations on their involvement in CSR initiatives. Abhigyan 35(4):31-42

171. Saunders S, Lewis M, Thornhill D (2009) Research methods for business students. Pearson Education Limited, Harlow

172. Saxena A (2014) Workforce diversity: a key to improve productivity. Procedia Econ Finance 11:76-85

173. Schmeltz A (2012) Consumer-oriented CSR communication: focusing on ability or morality? Corp Commun Int J 17(1):29-49

174. Scott A (1955) Reliability of content analysis: the case of nominal scale coding. Public Opin Q 19(3):321-325

175. Shareef A, Arunachalam W, Sodique D, Davey F (2014) Understanding CSR in the Maldivian context. Soc Responsib J 10(1):85-114

176. Sharma S, Mishra P (2019) Hotel employees' perceptions about CSR initiatives and there potential to support the skill India initiative. Worldw Hosp Tour Themes 11(1):78-86

177. Simnett A, Vanstraelen W, Chua C (2009) Assurance on sustainability reports: an international comparison. Acc Rev 84(3):937-967

178. Stemler S (2001) An overview of content analysis. Pract Assess Res Eval 7(17):137-146

179. Taherdoost H (2016) Sampling methods in research methodology; how to choose a sampling technique for research. Int J Acad Res Manag 5(2):18-27

180. Tilakasiri KK (2012) Corporate social responsibility and company performance: evidence from Sri Lanka. Victoria University, Melbourne

181. Tilt R (2016) Corporate social responsibility research: the importance of context. Int J Corp Soc Responsib 1(2):5

182. Trang NT, Yekini A (2014) Investigating the link between CSR and Financial performance - evidence from Vietnamese listed companies. Br J Arts Soc Sci 17(1):85-101

183. Tsavdaridou A, Metaxas D (2015) A theoretical framework on CSR and urban development. Munich Personal RePEc Archive, pp 1-15

184. Turban DB, Greening DW (1996) Corporate social performance and organizational attractiveness to prospective employees. Acad Manag J 40(3):658-672

185. Ugur S, Yarimoglu YK (2015) Employees' perspectives on corporate social responsibility: a focus group study in Izmir City. J Yasar Univ 10(1):68-74 
186. Ujunwa R (2012) Board characteristics and the financial performance of Nigerian quoted firms. Corp Govern 12(5):656-674

187. Ukachukwu CC, Iheriohamma EBJ (2013) The effect of cultural diversity on employee productivity in work organizations in Port Harcourt, Nigeria. Int J Dev Manag Rev 8(1):32-49

188. Vance SC (1975) Are socially responsible corporations good investment risks. Manag Rev 64(8):19-24

189. Vatcheva A, Lee D, McCormick M, Rahbar N (2016) Multicollinearity in regression analyses conducted in epidemiologic studies. Epidemiology (Sunnyvale Calif) 6(2):227

190. Vollero A, Conte F, Siano A, Covucci C (2019) Corporate social responsibility information and involvement strategies in controversial industries. Corp Soc Responsib Environ Manag 26(1):141-151

191. Waddock R, Graves S (1997) The corporate social performance-financial performance link. Strateg Manag J 18(4):2-34

192. Wahba A (2008) Does the market value corporate environmental responsibility? An empirical examination. Corp Soc Responsib Environ Manag 15(2):89-99

193. Wahba A (2010) How do institutional shareholders manipulate corporate environmental strategy to protect their equity value? A study of the adoption of ISO 14001 by Egyptian firms. Bus Strategy Environ 19(8):495-511

194. Walker A, Kent B (2009) Do fans care? Assessing the influence of corporate social responsibility on consumer attitudes in the sport industry. J Sport Manag 23(1):743-769

195. Wang $S$ et al (2015) Opening the black box of CSR decision making: a policy-capturing study of charitable donation decisions in China. J Bus Ethics 128(3):665-683

196. Wang S (2015) Chinese strategic decision-making on CSR. Springer, New York

197. Waworuntu S, Wantah D, Rusmanto F (2014) CSR and financial performance analysis: evidence from top ASEAN listed companies. Procedia Soc Behav Sci 164:493-500
198. White $D$ (1999) Managing the diverse organization: The imperative for a new multicultural paradigm. Public Admin Manag Interact J 4(4):469-493

199. Williams S (1999) Voluntary environmental and social accounting disclosure practices in the Asia-Pacific region: an international empirical test of political economy theory. Int J Account 34(2):209-238

200. Wooldridge D (2013) Introductory econometrics: a modern approach. South-Western, Cengage Learning, Mason

201. Wu L, Shao Z, Yang C, Ding T, Zhang W (2020) The impact of CSR and financial distress on financial performance-evidence from Chinese listed companies of the manufacturing industry. Sustainability 12(17):6799

202. Xiao JZ, Gao S, Heravi S, Cheung CQ (2005) The impact of social and economic development on corporate social and environmental disclosure in Hong Kong and the U.K. Adv Int Account 18:219-243

203. Yang J, Zhang D, Jiang B, Sun E (2015) Strategic flexibility, green management, and firm competitiveness in an emerging economy. Technol Forecast Soc Change 101(1):347-356

204. Yang SL, Shiu YM, Liu TC (2015) Reexamination of the insurance-like effect of corporate social responsibility: Empirical evidence from Chinalisted companies. Chin Manag Stud 9(3):295-310

205. Yeganeh X, Barzegar D (2014) The effect of disclosure level of corporate social responsibility (CSR) on corporate financial performance (CFP) in Tehran stock exchange. Int J Acc Res 1(11):43-51

206. Yoon R, Lee S (2016) What makes employees zealous supporters of their firm's CSR initiative? the role of employees' perceptions of their firm's CSR authenticity. Adv Group Processes 33:93-126

207. Zhao X, Lee S, Moon L (2019) Employee response to CSR in China: the moderating effect of collectivism. Pers Rev 48(3):839-863

208. Žmuk B, Lutilsky R, Dragija B (2016) The choice of a sampling procedure for a (too) small target population: the case of Croatian public hospitals. Zbornik Ekonomskog fakulteta u Zagrebu 14(2):19-44

\section{Submit your manuscript to a SpringerOpen ${ }^{\circ}$ journal and benefit from:}

- Convenient online submission

- Rigorous peer review

- Open access: articles freely available online

- High visibility within the field

- Retaining the copyright to your article

Submit your next manuscript at $\boldsymbol{\nabla}$ springeropen.com 